Jurnal Geografi, Edukasi dan Lingkungan (JGEL) Vol. 4, No. 1, Januari 2020:17-24

P-ISSN: 2579-8499; E-ISSN: 2579-8510

Doi: https://doi.org/10.29405/jgel.v4i1.3927

Website: http://journal.uhamka.ac.id/index.php/jgel

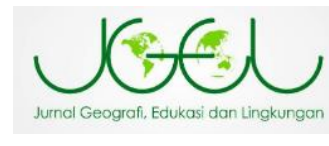

\title{
Paleogeografi: Perkembangan Keanekaragaman Hayati Dalam Ruang Dan Waktu (Biodiversity In Time And Space)
}

\author{
Revi Mainaki*, dan Anita Eka Putri \\ Jurusan Pendidikan Geografi, Fakultas Keguruan dan Ilmu Pendidikan \\ Universitas Siliwangi, Tasikmalaya Jawa Barat 64115 \\ *E-mail: revi.mainaki@unsil.ac.id \\ Received: 25112019 / Accepted: 17122019 / Published online: 30012020
}

\begin{abstract}
ABSTRAK
Kajian tentang permukaan bumi tidak lepas dari aspek biosfer yang membahas keanekaragaman hayati. Dalam memahami perlu mengetahui sejarah perkembangan kenaekaragaman hayati di permukaan bumi. Paleogeografi merupakan cabang kajian aspek biosfer berbicara mengenai aspek tersebut. Melalui kajian pustaka artikel ini berusaha menguraikan dan mendeskripsikan perkembangan keanekaragaman hayati di dunia berdasarkan kala geologi. Metode yang digunakan berdasarkan kajian literature, dari buku dan jurnal. Hasil penelitian menunjukan perkembangan flora di dunia diawali dengan munculnya algae, fungi dan schizophyta sebagai spesies pertama, dan stabil di setiap masa. Spesies lain muncul di Era Paleozoikum tepatnya masa silur yakni nemathopytale dan psilopsida. Pada masa devon muncul spesies lain dengan jumlah terbatas dan Masa Karbon flora mulai berkembang menjadi heterogen sampai kepunahan masal di Masa Perm, tetapi kembali berkembang di Era Mesozoikum. Sedangkan fauna diawali dengan munculnya cacing dan protozoa yang berkembang dari masa tersier hingga kambrium jenis porifera, coelenterata, bryozoa, brachiopoda, echinodermata, mollusca, cacing, anthropoda dan chordata. Pada Masa Kambrium muncul hewan bertulang belakang, diawali dengan jenis ikan diikuti oleh placedorm di Masa Silur dan punah pada Masa Trias terus berfluktuatif juga dengan kemunculan jenis amfibi. Pada Masa Permian muncul jenis reptil disusul mamalia di Masa Trias dan burung di Masa Jura sebagai hasil evolusi reptile. Jenis primata dan manusia mulai muncul di Era Keneozoikum, pada Masa Tersier, Zaman Paleosen yang ditemukan muncul di Benua Eropa, Amerika Utara dan Asia. Teori evolusi masih menjadi salah satu acuan perkembangan keanekaragaman hayati dari masa ke masa yang didasarkan oleh perubahan DNA dan RNA pada makhluk hidup.
\end{abstract}

Kata Kunci: Paleogeografi, Flora, Fauna, dan Evolusi

\section{ABSTRACT}

The study of the surface of the earth is inseparable from aspects of the biosphere that discuss biodiversity. To understand, we need to know the history of the development of biological diversity on the surface of the earth. Paleogeography as one branch of the study of aspects of the biosphere talks about that aspect. Through literature review this article seeks to describe and describe the development of biodiversity in the world based on geological time. The method that has been used is literature study. The results showed that the development of flora in the world began with the emergence of algae, fungi and schizophyta as the first and stable species at any time, other species appeared in the 
Paleozoic Era precisely the silur period namely nemathopytale and psilopsida, during the devon period appeared other species with limited numbers and Carbon Period flora began to develop into heterogeneous until the mass extinction in the Perm Period, but redeveloped in the Mesozoic Era. Whereas fauna begins with the emergence of worms and protozoa that develop from the tertiary to cambular types of porifera, coelenterata, bryozoa, brachiopoda, echinoderms, molluscs, worms, anthropods and chordates. During the Cambrian Period vertebrates appear, beginning with the type of fish followed by a placedorm in the Silurian Period and extinction during the Triassic period also fluctuates with the appearance of amphibians. During the Permian period reptiles emerged followed by mammals in the Triassic period and birds in the Jurassic Period as a result of reptile evolution, primate species and humans began to appear in the Ceneozoic Era, in the Tertiary Period, the Paleocene Age which were found to appear in Europe, North America and Asia. The theory of evolution is still one of the references to the development of biodiversity from time to time based on changes in DNA and RNA in living things.

Keywords: Paleogeography, Flora, Fauna, and Evolution

\section{PENDAHULUAN}

Sesuai dengan namanya paleogeografi adalah salah satu cabang ilmu yang mengkaji tentang perkembangan kondisi geografis dari masa ke masa dan kaitannya dengan keanekaragaman hayati di dunia (Ridhwan, 2012). Keanekaragaman hayati mencakup ke dalam semua bentuk kehidupan (Sutoyo, 2010). Keaneka-ragaman hayati dipandang sebagai suatu pondasi dalam kehidupan manusia karena terkait dengan ekosistem di mana manusia hidup (Samedi, 2015). Kajian ini penting untuk juga membantu memahami asal mula perkembangan berbagai jenis spesies yang ada di bumi.

Bagaimana manusia bisa mengetahui perkembangan tersebut? Padahal belum ada tulisan atau manusia yang mendokumentasikannya. Jawabannya adalah dengan mempelajari lapisan batuan dari struktur bumi, dengan prinsip lapisan yang paling atas adalah lapisan yang paling muda sebaliknya, lapisan bumi yang paling bawah adalah lapisan yang paling tua. Sehingga para peneliti melakukan pengelompokan berdasarkan masa tertentu terhadap lapisan batuan di permukaan bumi yang disebut dengan Kala Geologi (Geologi Time) seperti pada Gambar 1.

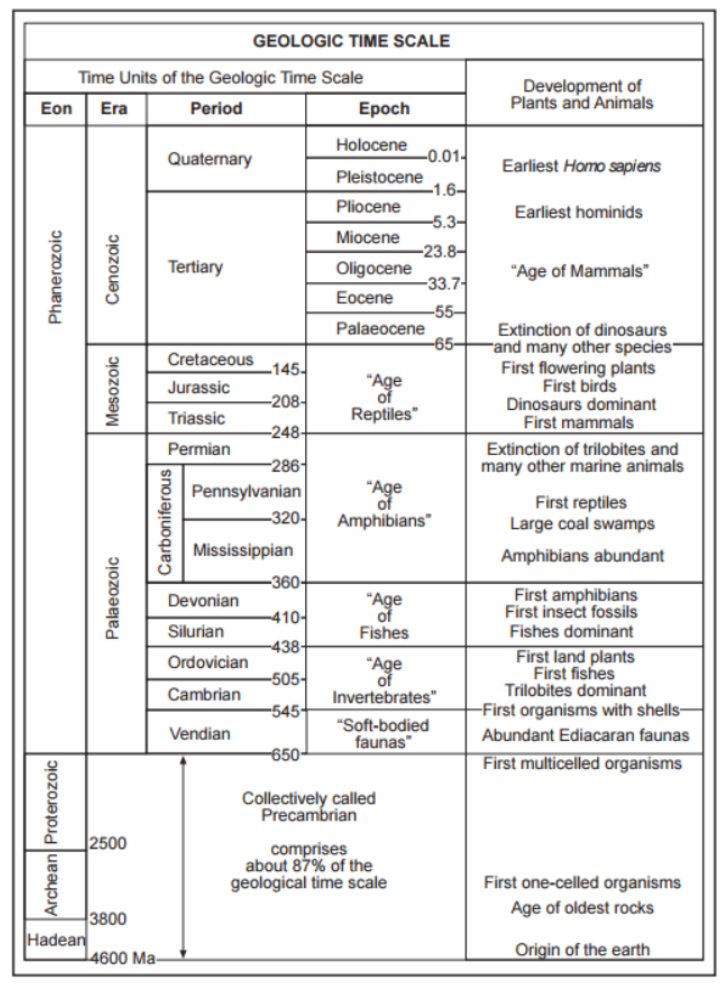

Gambar 1. Kala waktu geologi (McConnell, Steer, Knight, \& Owens, 2018) 
Pada Gambar 1 pembagian lapisan kulit bumi berdasarkan usianya, ada era yang kemudian diuraikan dalam beberapa masa, kemudian masa yang diuraikan kembali menjadi beberapa zaman. Ada 4 era yakni Prakambrium, era Paleozoikum yang dibagi dalam masa Kambrium, Ordovician, Silur, Devon, Carbon dan Perm, Era Mesozoikum yang terbagi dalam masa Triasic, Jurasic dan Cretasius dan terakhir adalah era Kenozoikum yang terbagi dalam masa Tersier teurai dalam zaman Eosin, Eligosen, Miosen dan Pleistosen serta zaman Kuater diurai dalam zaman Plestosen dan Holosen. Terlihat bahwa manusia sampai saat ini hanya mengetahui perkembangan kehidupan sampai lapisan yang berusia sekitar 600 juta tahun yang lalu, masa yang lebih tua dari itu tidak diketahui bagaimana perkembangannya.

Hakekatnya kondisi lingkungan di masa berjuta tahun lalu dan saat ini sangat berbeda jauh, perbedaan tersebut kemudian mempengaruhi kondisi makhluk hidup untuk dapat menyesuaikan diri dengan kondisi lingkungannya. Manusia adalah makhluk hidup yang dapat menyesuaikan diri dengan perubahan lingkungan yang ada sampai sekarang, seperti Solbrig \& Solbrig (1979) menyatakan: "Looking at environments fluctu-ations in terms of space and time, one can observe a veritable crazy quilt of ever changing conditions. At each point existing organisms reflect in theirs genetic constitution and morphological makeup their adapttion to the then present environmental conditions..."

Kondisi lingkungan yang terus berkembang membuat makhluk hidup yang diatasnya juga ikut berkembang. Perkembangan tersebut diamati dengan penemuan berbagai fosil, bagaimana proses terjadinya fosil dapat dilihat pada Gambar 2. Salah satu makhluk hidup minum di pinggir sungai kemudian dia terpeleset jatuh ke sungai dan mati tenggelam membuat hewan tersebut terendapkan di dasar sungai. Selama berjuta tahun bangkai makhluk hidup tersebut terkubur oleh sedimentasi di sungai dan kemudian sungai mengering. Bangkai tetap berada di lokasi tersebut yang akhirnya tubuhnya yang terkubur menyisakan tulang belulang yang kemudian diteliti di masa sekarang.

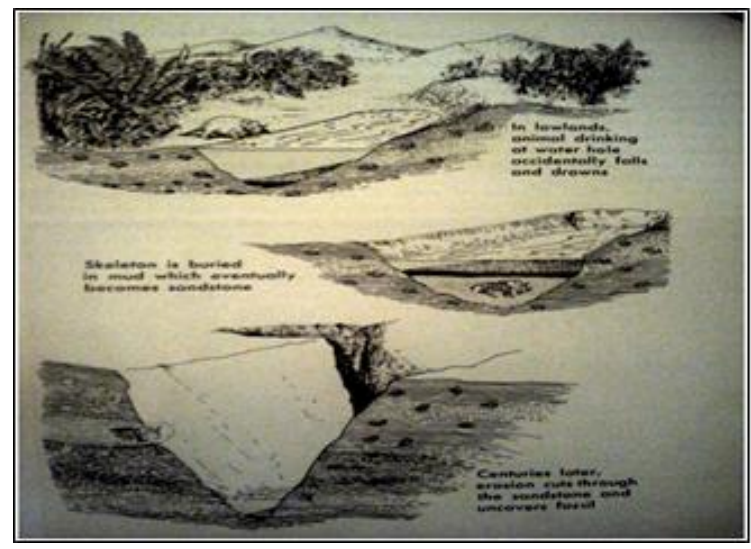

Gambar 2. Proses salah satu hewan menjadi fosil

(Sumber : Solbrig, 1979

Paleogeografi bumi mengkaji keanekaragaman hayati yang ada, dari masa ke masa dipengaruhi oleh waktu dan ruang geografis yang terus berkembang (Biodiversity in Space and Time). Beberapa penyebab dari perkembangan keanekaragaman hayati salah satunya dikemukakan oleh Polunin (1960) dengan perluasan dan modifikasi) yakni:

1. Kondisi iklim yang mengalami perubahan dari setiap era yang dapat diidentifikasi dari kondisi lapisan batuan dan fosil peninggalannya.

2. Kondisi tanah yang meliputi susunan kimia, kondisi fisik dan organiknya kemungkinan membuat setiap spesies berubah menjadi heterogen.

3. Kondisi organisme itu sendiri menjadi sebuah persaingan di bumi untuk memenuhi kebutuhan hidupnya, munculnya hukum rimba yang dapat bertahan dan menyesuaikan diri 
dengan lingkungannya akan terus berkembang berevolusi.

Sejauh ini manusia hanya mengetahui kondisi keanekaragaman hayati yang ada sampai usia sekitar 600 juta tahun. Berdasarkan lapisan tertua yang ada di bumi yang hanya berada di beberapa tempat yang ada di dunia. Melalui artikel ini penulis berusaha menguraikan bagaimana perkembangan keanekaragaman hayati atau flora dan fauna di dunia dari awal hingga saat ini sehingga diperoleh gambaran untuk penelitian lebih lanjut.

\section{METODE PENELITIAN}

Guna menjelaskan perkembangan keanekaragaman hayati dalam ruang dan waktu dengan cangkupan general di dunia, penulis menggunakan studi literatur. Hal ini bertujuan untuk menjelaskan apa yang menjadi tujuan penelitian melalui pengkajian berbagai referensi ilmiah dalam bentuk jurnal, makalah dan publikasi hasil penelitian lainnya yang relevan. Selanjutnya, dilakukan analisis dan didapatkan hasil sesuai dengan tujuan penelitian.

\section{HASIL DAN PEMBAHASAN}

Perkembangan Keanekaragaman Haya-ti dalam Ruang dan Waktu (In Space And Time)

Seperti telah dikemukakan sebelumnya tentang hakekat dari paleogeografi yang meliputi perkembangan keanekaragaman makhluk hidup berdasarkan ruang dan waktu, kondisi keanekaragaman hayati di setiap era berdasarkan hasil penemuan fosil di permukaan bumi dapat diklasifikan menjadi dua yakni perkembangan flora dan fauna, karena kondisi ruang atau kondisi geografis planet bumi mengalami dinamika tertentu yang mengakibatkan perkembangan keanekaragaman hayati. Salah satu gambaran dari perubahan kondisi geografi dapat dilihat pada Gambar 3.

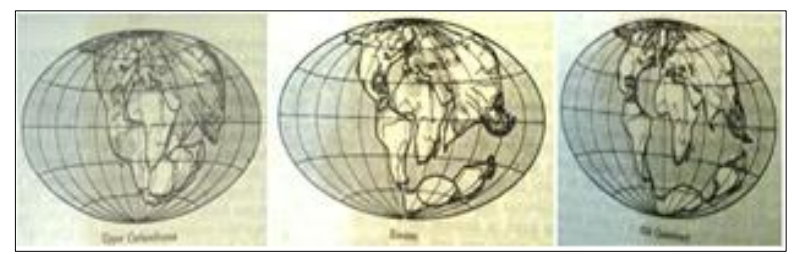

Gambar 3. Perubahan daratan bumi dari masa ke masa yang mempengaruhi kondisi makhluk hidup yang ada diatasnya (Polunin, 1960).

\section{Perkembangan Keanekaragaman Flora Dunia}

Untuk perkembangan keaneka ragaman flora yang ada di dunia dapat dilihat pada Gambar 4. Semakin besal bulatan hitam artinya populasi spesies tersebut semakin banyak. Berdasarkan Gambar 4 terlihat bahwa Algae, Fungi dan Schizophyta populasinya selalu stabil dari masa ke masa yang menunjukan daya tahan atau daya adaptasi ketiga spesies tersebut cukup baik untuk bertahan menghadapi kondisi ruang geografis yang berubah-ubah. Sementara untuk spesies lain muncul pada Era Paleozoikum awal yakni jenis Nemathopytale dan Psilopsida tepatnya di masa silur sehingga masih relatif homogen spesies floranya.

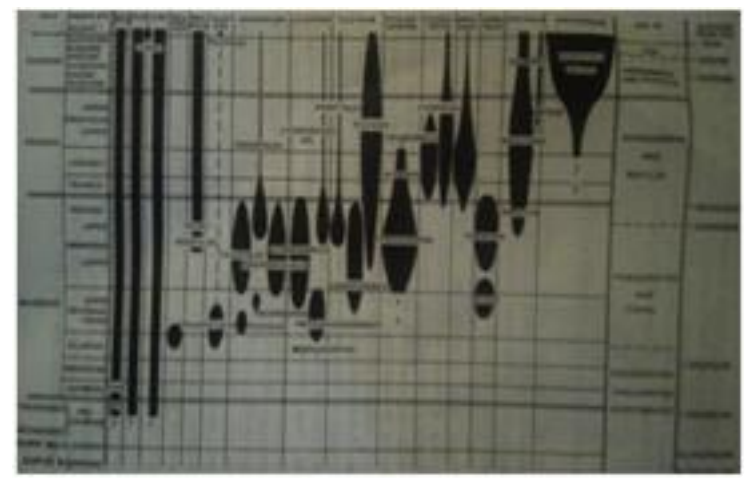

Gambar 4. Kondisi keanekaragaman jenis flora di permukaan bumi (Arnold, 2010)

Masuk di Masa Devon mulai muncul spesies flora baru dengan jumlah yang masih terbatas. Baru pada masa karbon flora berkembang dengan sangat 
baik dari segi varietas lebih banyak dibanding pada Masa Sebelumnya. Bisa dikatakan di Era Paleozoikum, Masa Devon sampai Masa Perm merupakan keanekaragaman flora terbesar sepanjang sejarah bumi (Gambar 5).

Namun, di masa Permian terjadi kepunahan masal flora dan hanya sedikit yang dapat bertahan di Era berikutnya. Kepunahan tersebut belum dapat dipastikan faktornya kenapa bisa terjadi ke-punahan. Memasuki Era Mesozoikum kembali muncul flora dengan spesies baru dengan jumlah yang relatif banyak namun tidak seberagam di Era Paleozoikum. Kemudian kondisi bumi yang terus berkembang juga menyebabkan hanya sedikit flora yang dapat bertahan sampai saat ini dengan jumlah yang menurun cukup drastis bahkan punah. Namun sebaliknya untuk jenis flora Angiospermae yang awalnya berjumlah sedikit mengalami perkembangan yang jumlahnya meningkat hingga saat ini.

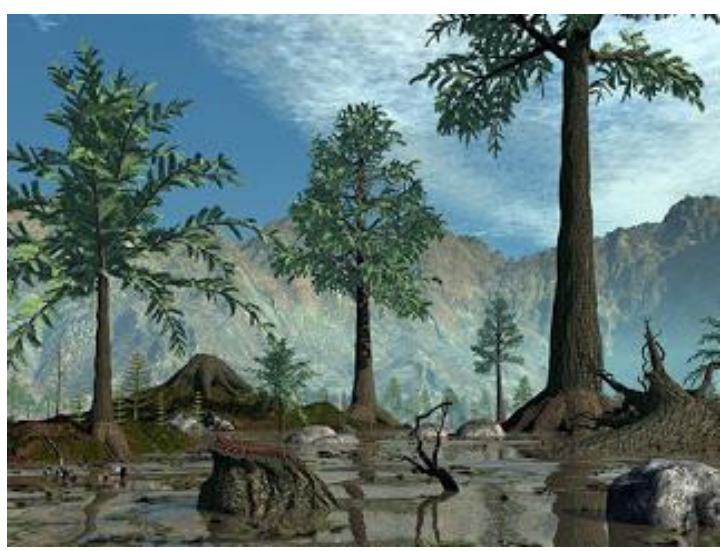

Gambar 5. Ilustrasi jenis flora di hutan pada Masa Devon berdasarkan fosil pada lapisan ini (Polunin, 1960)

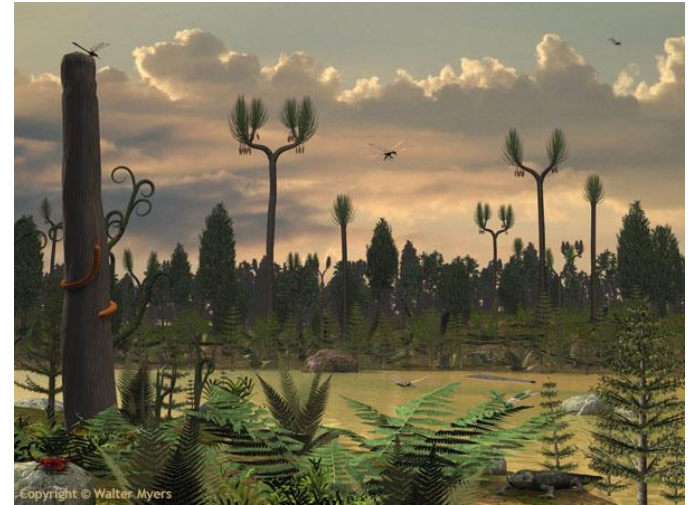

Gambar 6. Ilustrasi jenis flora di hutan pada

Masa Karbon berdasarkan penemuan fosil pada lapisan ini (Polunin, 1960)

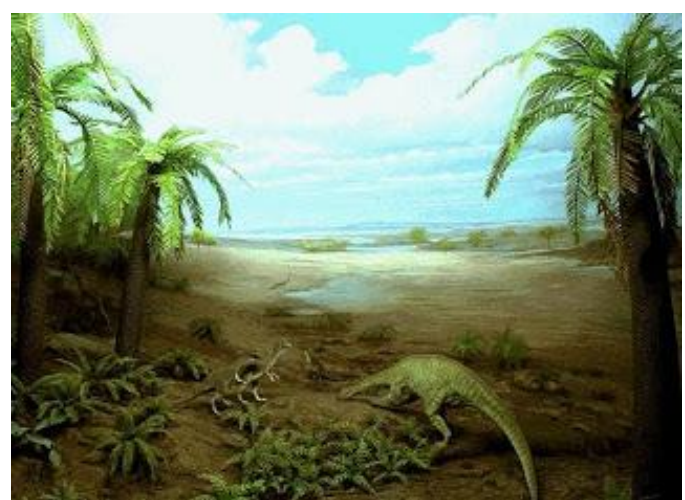

Gambar 7. Ilustrasi jenis flora di hutan pada Masa Trias berdasarkan penemuan fosil pada lapisan ini. (Polunin, 1960)

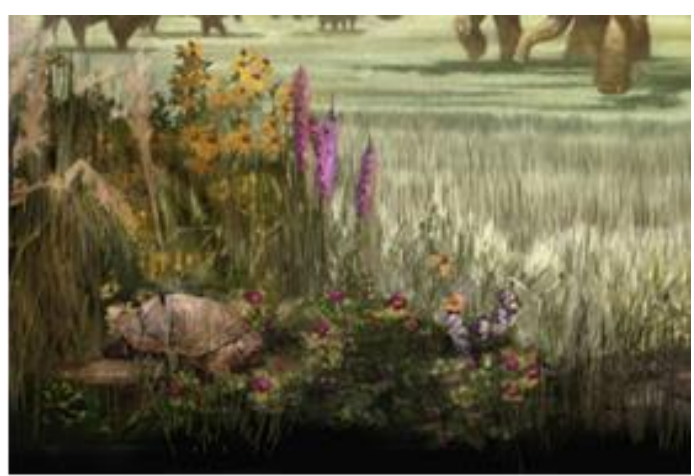

Gambar 8. Ilustrasi jenis flora di hutan pada Masa Tersier, Zaman Miosen berdasarkan penemuan fosil pada lapisan ini. (Polunin, 1960)

\section{Perkembangan Keanekaragaman Fauna Dunia}

Fauna yang pertama kali muncul berdasarkan fosil yang ditemukan adalah jenis hewan yang masih sederhana dan tidak memiliki kulit luar seperti cacing dan 
protozoa. Pada Gambar 9 dapat dilihat bahwa keanekaragaman fauna dari masa kambrium hingga tersier berkembang dengan jumlah yang terus naik dengan jenis fauna Protozoa, Porifera, Coelenterata, Bryozoa, Brachiopoda, Echinodermata, Mollusca, Cacing, Anthropoda dan Chordata. Keanekaragaman kembali muncul seperti pada Gambar 9 yakni perkembangan dari jenis hewan bertulang belakang (vetebrata).

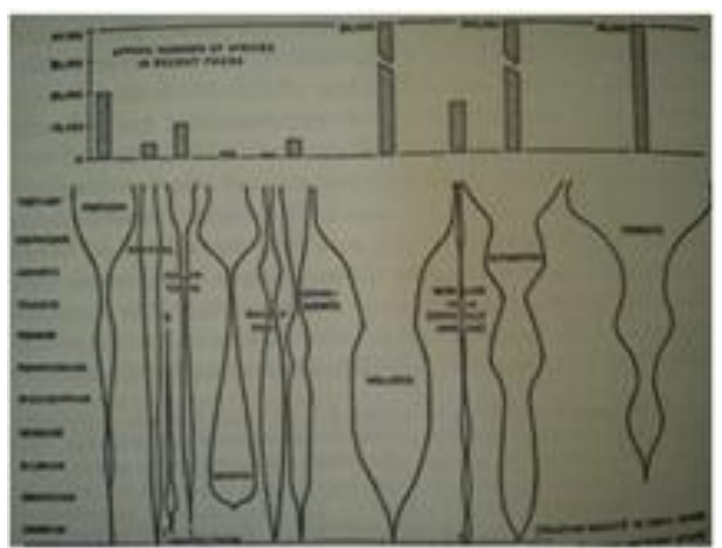

Gambar 9. Grafik fauna yang pertama kali muncul dan perkembangannya (Simpson \& Simpson, 1949)

Hewan bertulang belakang seperti pada Gambar 10, baru muncul pada Masa Kambrium diawali oleh jenis ikan yang jumlahnya terus menurun hingga sekarang. Selanjutnya, disusul pada Masa Silur dengan Placedorms yang punah pada Masa Trias, muncul pada Masa Devon jenis ikan lain yang jumlahnya sempat menurun di masa Trias namun kembali bertambah pada masa-masa berikutnya. Pada masa devon juga muncul jenis amphibi dengan jumlah yang fluktuatif pada setiap Masa Berikutnya. Reptile mulai muncul pada pertengahan Masa Permian yang jumlahnya juga mengalami fluktuasi. Kemunculan reptile kemudian disusul oleh munculnya mamalia pertama di Masa Trias dan burung pertama pada Masa Jura yang menurut beberapa ilmuan berasal dari adaptasi atau perkembangan dari jenis reptile.

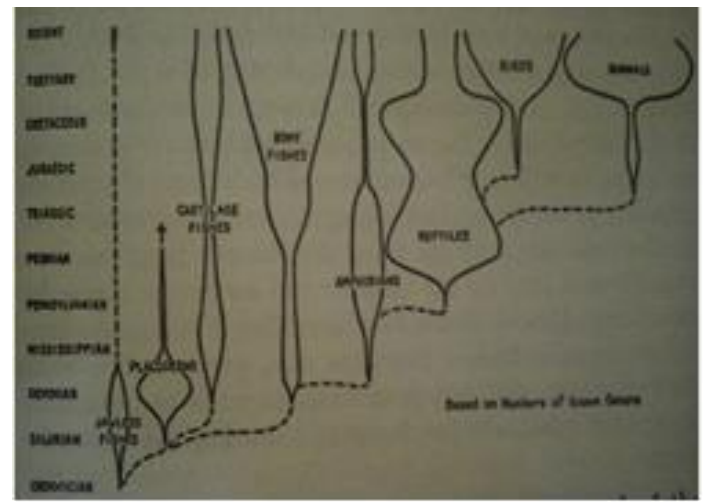

Gambar 10. Grafik Perkembangan hewan bertulang belakang (vetebrata) (Simpson \& Simpson, 1949)

Sementara untuk perkembangan jenis primata dan fosil manusia sendiri itu baru ditemukan pada lapisan di awal Era Keneozoikum, pada Masa Tersier, Zaman Paleosen. Seperti pada Gambar 11 yang mengungkapkan bahwa primata pertama kali muncul di benua Eropa, Amerika Utara dan Asia dengan jumlah yang masih sedikit dan mengalami kepunahan. Kecuali yang terdapat di Asia yang masih berkembang hingga saat ini yakni sejenis Lemur. Primata di Eropa kembai muncul pada Zaman Oligosen. Begitu pula di belahan dunia lain primata fosilnya baru diketemukan pada masa Eosen dan terus berkembang hingga sekarang.

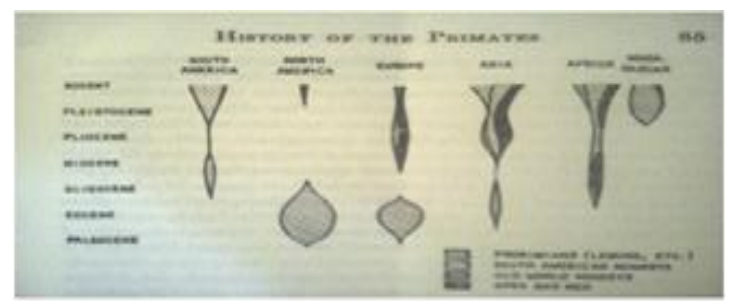

Gambar 11. Grafik Perkembangan primata (Simpson \& Simpson, 1949)

\section{Evolusi dan Keanekaragaman Hayati}

Salah satu teori yang beranggapan bahwa faktor yang menyebabkan munculnya banyak spesies di permukaan bumi adalah teori evolusi. Teori ini salah 
satunya didasarkan pada kondisi lingkungan bumi yang terus mengalami perkembangan, dan makhluk hidup yang dapat bertahan telah mengalami evolusi sementara spesies yang tidak dapat bertahan akan mengalami kepunahan. Teori evolusi juga didasarkan pada perubahan DNA dan RNA makhluk hidup yang disebabkan oleh radiasi dimana planet bumi pada saat setelah pembentukan kondisinya masih belum stabil (Simpson \& Simpson, 1949). Berdasarkan bukti fosil diketemukan bahwa burung berasal dari perkembangan reptile. Tentu saja teori ini masih diragukan karena penemuan fosil masih belum dapat mengungkapkan apa yang sebenarnya penyebab keanekaragaman fauna (Gambar 12).

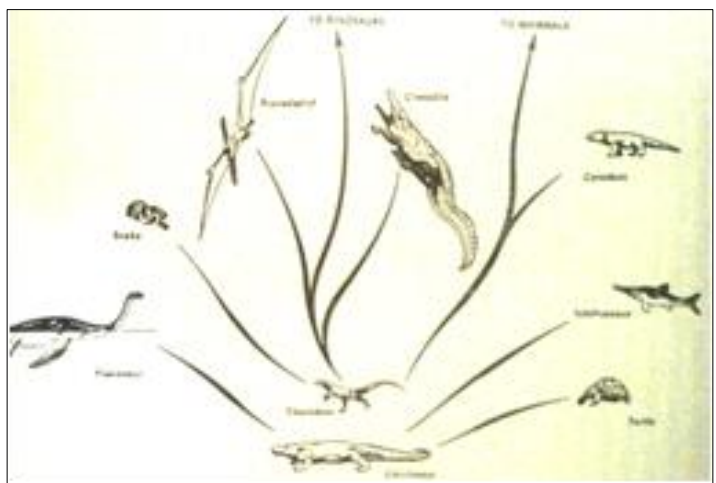

Gambar 12. Evolusi reptile akibat dari radiasi di planet bumi pada kuda menyebabkan perkembangan keaneka-ragaman Fauna dunia (Simpson \& Simpson, 1949).

\section{KESIMPULAN}

Bahasan tentang permukaan bumi tidak boleh lepas dari aspek biosfer yang berbicara mengenai keanekaragaman hayati flora dan fauna dipermukaan bumi. Untuk memahami kondisi flora dan fauna dipermukaan bumi saat ini kita perlu mengkaji bagaimana asal mula keberadaannya, salah satunya dengan pendekatan kala geologi atau usia lapisan permukaan bumi. Kemunculan flora diawali dengan Algae, Fungi dan Schizophyta kemudian diikuti oleh nemathopytale dan psilopsida pada Era Paleozoikum punah pada masa tersebut dan kembali berkembang di Era Mesozoikum sampai saat ini menjadi lebih heterogen.

Perkembangan fauna diawali dengan perkembangan hewan tidak bertulang belakang pada Masa Tersier. Selanjutnya, diikuti dengan kemunculan hewan bertulang belakang pada Masa Kambrium yang diawali dengan jenis ikan dan terus mengalami fluktuatif dengan kemunculan amfibi, reptile dan burung di Masa Silur, Permian, Jura dan Trias. Kemunculan primata dan manusia diperkirakan pada Era Kenezoikum Benua Eropa, Amerika Utara dan Asia. Teori evolusi masih menjadi salah satu rujukan dalam menjelaskan fenomena perkembangan keanekaragaman hayati tersebut.

\section{DAFTAR PUSTAKA}

Arnold, C. A. (2010). An introduction to paleobotany. [S.1.]: [Miller Press].

McConnell, D., Steer, D. N., Knight, C., \& Owens, K. (2018). The good Earth: introduction to earth science.

Polunin, N. (1960). Introduction to plant geography and some related sciences. Retrieved from https://www.biodiversitylibrary.org/i tem/40842

Ridhwan, M. (2012). Tingkat Keanekaragaman Hayati Dan Pemanfaatannya Di Indonesia. Jurnal Biology Education, 1(1), 1-17.

Samedi. (2015).

Konservasi KeaneKaragaman Hayati di indonesia:

Konservasi Keanekaragaman Hayati di Indonesia: reKomendasi PerbaiKan Undang-Undang Konservasi. Hukum, Jurnal Vol, Lingkungan, 2(2), 1-28.

Simpson, G. G., \& Simpson, L. (1949). 
24 | Jurnal Geografi, Edukasi dan Lingkungan (JGEL) Vol. 4, No. 1, Januari 2020:17-24

The meaning of evolution: a study of the history of life and of its significance for man (Vol. 25). Yale University Press.

Solbrig, O. T., \& Solbrig, D. J. (1979). Introduction to population biology and evolution. Londres, UK. Addison--Wesley Pub.

Sutoyo. (2010). Keanekaragaman hayati indonesia, suatu tinjauan: Masalah dan pemecahanya. Buana Sains, 10, 101-106. 